\title{
Methodologies for the study of a vernacular built environment within a historic residential complex: The case of the village of Gornji Stoliv, Montenegro
}

\author{
Metodologías para el estudio de un entorno construido \\ vernáculo dentro de un complejo residencial histórico: \\ El caso del pueblo de Gornji Stoliv, Montenegro
}

\section{Metodologias para o estudo de um ambiente vernacular construído dentro de um complexo residencial histórico: O caso da aldeia de Gornji Stoliv, Montenegro}

\author{
Keywords | Palabras clave | Palavras chave \\ Rural architecture, Vernacular heritage, Architectural analysis, Bay of Kotor, Republic of Venice \\ Arquitectura rural, Patrimonio vernáculo, Análisis arquitectónico, Bocas de Kotor, República de Venecia \\ Arquitectura rural, Património Vernacular, Análise Arquitectónica, Baía de Kotor, República de Veneza
}

\begin{abstract}
Resumen | Resumo
The settlement of Gornji Stoliv is an abandoned rural ensemble located on the northern hillside of Mount Vrmac, in the Bay of Kotor, Montenegro. Including around six dozen residential, commercial and religious buildings, the village is a rare testimony to a social and architectural tradition that was developed throughout the Adriatic coast within the borders of the Republic of Venice from 1420 to 1797. A research conducted between December 2018 and May 2019 was the first wide-scale research into the historical, social, urban, and architectural characteristics and cultural landscape of the village since the 1950s. This paper presents the results of a comprehensive set of analyses carried out on the current state of conservation of the village and demonstrates the methodologies required to analyse a historical built environment of this kind in the absence of sufficient written and archival material.

El asentamiento de Gornji Stoliv es un conjunto rural abandonado situado en la ladera norte de la montaña de Vrmac, en las Bocas de Kotor, Montenegro. Formado por unos ochenta edificios residenciales, comerciales y religiosos, el pueblo es testigo excepcional de la tradición social y arquitectónica que se desarrolló en la costa del Adriático dentro de las fronteras de la República de Venecia, entre 1420 y 1797. Un estudio realizado entre diciembre de 2018 y mayo de 2019 fue la primera investigación a gran escala de las características históricas, sociales, urbanas, arquitectónicas y culturalespaisajísticas del pueblo desde los años 50 . El artículo presenta los resultados de una serie exhaustiva de análisis que aborda el actual estado de conservación del pueblo y fundamenta las metodologías necesarias para analizar un entorno construido histórico de este tipo cuando se carece de suficientes fuentes escritas y material de archivo.
\end{abstract}


A povoação de Gornji Stoliv representa um conjunto rural abandonado localizado na encosta norte do monte Vrmac, na Baía de Kotor, Montenegro. Incluíndo cerca de seis dezenas de edifícios residenciais, comerciais e religiosos, a aldeia é um testemunho raro de uma tradição social e arquitectónica que se desenvolveu ao longo da costa do Adriático, dentro das fronteiras da República de Veneza, de 1420 a 1797. Uma investigação realizada entre Dezembro de 2018 e Maio de 2019 foi a primeira investigação em larga escala sobre as características históricas, sociais, urbanas, arquitectónicas e culturais-paisagísticas da aldeia desde os anos 50. O artigo apresenta os resultados de um conjunto abrangente de análises realizadas, que aborda o estado actual de conservação da aldeia e fundamenta as metodologias necessárias para a análise deste tipo de ambiente histórico construído na ausência de material escrito e de arquivo suficiente.

\section{Introduction}

\section{Geographical context}

Situated on the northern hillside of the mount and peninsula of Vrmac at an altitude of 200 metres above sea level, and overlooking the Kotor basin of the Bay of Kotor (Fig. 1), in Montenegro, Gornji Stoliv (formerly also known as Stoliv, Stolivo and Stolivo Superiore) is currently an abandoned architectural ensemble (Fig. 2). The two last remaining inhabitants occupy a single household and engage in a limited array of agricultural activities. It used to have dozens of households and a functioning socio-economic environment. The buildings and plots of the settlement include churches, residences of diverse character, mills, and cisterns, as well as chestnut forests, olive groves and vineyards. All this testifies to what was, for centuries, a prosperous settlement developing within the economic, social and cultural prosperity of the area, as ushered in by the rule of the Republic of Venice (1420-1797).

The present-day division of the wider area of Stoliv into the settlements of Gornji (Upper) Stoliv and Donji (Lower) Stoliv down by the coast (Fig. 3) dates back to the period in which the Venetians completed their domination over the whole area of the Bay of Kotor, following the retreat of the Ottoman Empire from the western portion of the bay in the late $17^{\text {th }}$ century. From that point on the threat of Ottoman conquest had been removed and this arguably allowed for the formation of a settlement on the coast itself - that of
Figure 1. Basins of the Bay of Kotor (Author, on Google Maps base)

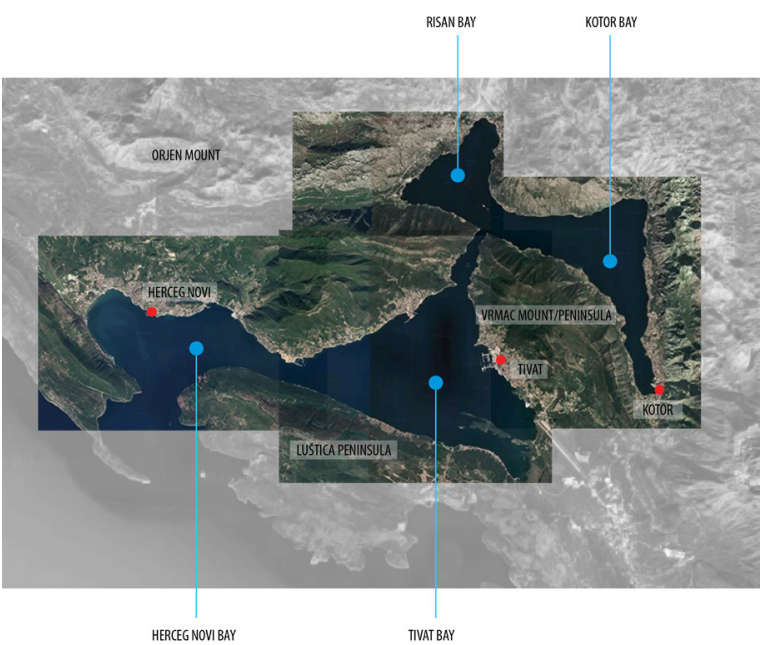

Figure 2. View of Gornji Stoliv from the access pathway

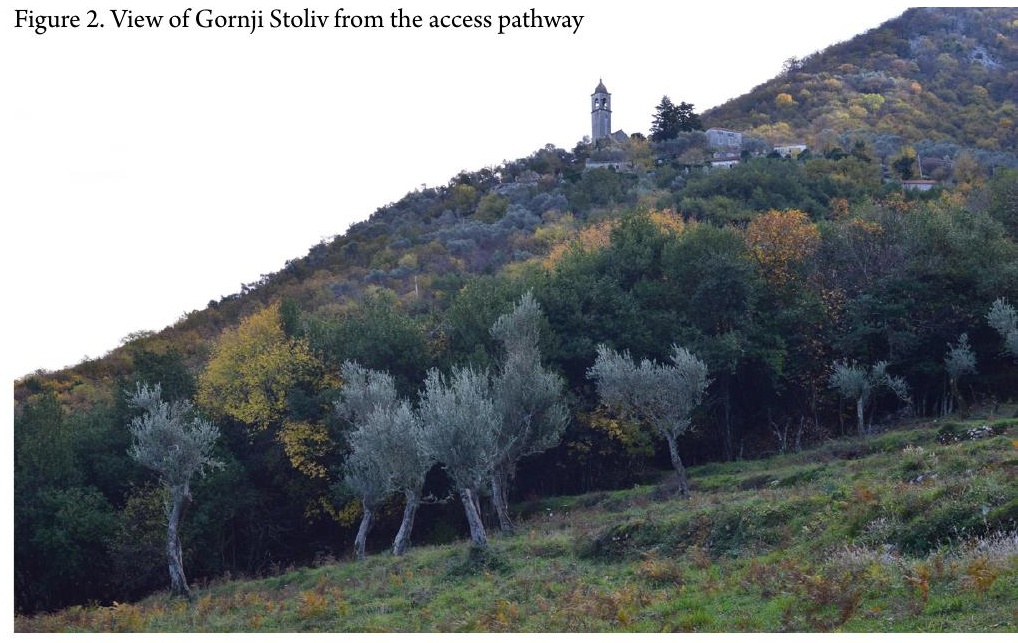




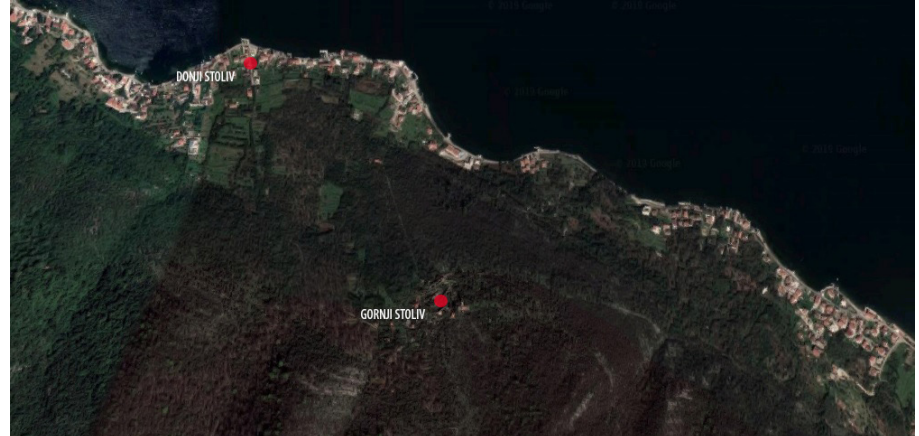

Figure 3. Aerial view of the wider area of Stoliv (Author, on Google Maps base)

Donji Stoliv. The two settlements are now connected by a stone-paved pathway, which remains the main route connecting Gornji Stoliv to the settlement and the vehicular route along the coast. Apart from this pathway, three other ones lead east-, south- and westwards, connecting Gornji Stoliv to the Vrmac settlements of Prčanj, Gornja Lastva and Lepetane respectively. The connection of Gornji Stoliv with Donji Stoliv is arguably one of the last remaining ones of this kind in the Bay of Kotor and the UNESCO World Heritage Site of the "Natural and Culturo-Historical Region of Kotor". The traditional configuration of the cultural landscape surrounding its historic settlements still remains largely intact to this day, as can be seen in the layout of the built environment of the two aforementioned settlements (Fig. 4). Despite this degree of authenticity and integrity of the settlements and their immediate surroundings, inadequate architectural typologies, coupled with a gradual urban sprawl, have already started to appear in Donji Stoliv, albeit at a slower rate than in other parts of the World Heritage Site and the bay as a whole. This trend, however, has already started to undermine the natural and cultural qualities of the plots surrounding Donji Stoliv, resulting in the partial loss of traditional plants, drywalls, etc. In addition, the overall uniqueness of Donji Stoliv has also been affected by negative forms of urbanisation. The traditional compact urban fabric has given way to linear development along the coast, echoing the incompatibility of the new construction activities with the historic built environment of both Donji Stoliv and the Bay of Kotor in general.

\section{$\underline{\text { Historical overview }}$}

Following a process of de-urbanisation in the early Middle Ages and the Slavic inhabitation of the area in the $7^{\text {th }}$ century, the wider region of the Vrmac peninsula saw the formation of villages (Mažibradić, 2016). While the existence of habitation in the area prior to the $12^{\text {th }}$ century is disputed (Korać 1953), the use of Vrmac's arable plots was disputed between the nearby ecclesiastical establishments, the nobility, and land-owning laymen from the district of Kotor (Sindik 1950). This may be partly responsible for the dispersed configuration of dwellings around the peninsula. Another characteristic of Vrmac's rural settlements in the late-medieval and early-Modern periods is that they were

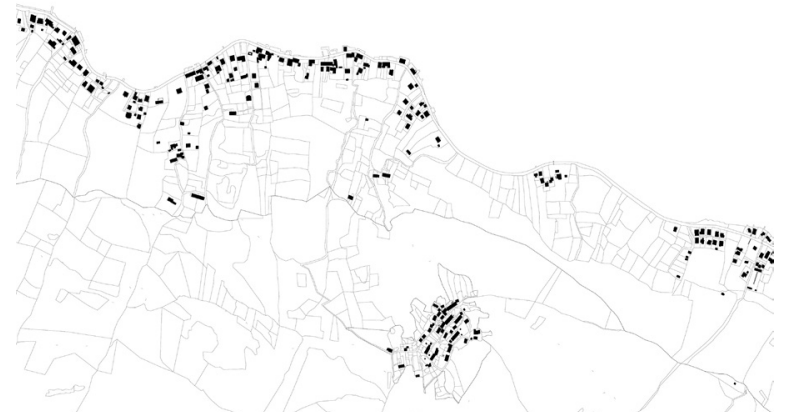

Figure 4. Site plan of the wider area of Stoliv

located only on the higher slopes of the mountains due to the threat of pirate and Ottoman attacks on the coast (Lisavac 2019). It should further be noted that the early formation of the cultural landscape of Vrmac was marked primarily by the architectural interventions of the nobility from Kotor. In other words, by summer residences with gardens and chapels, to which the serfs were bound both economically and spatially. Due to limited arable land, the plots came to be organised in the form of terraced patches of land supported by retaining walls (Lisavac 2019). The dispersed nature of the dwellings (or clusters of dwelling) on the Vrmac peninsula arguably ended with the increase in political security and following a series of devastating earthquakes, all of which ended by the late $17^{\text {th }}$ century. Henceforth the settlements started to take on a more compact configuration, allowing for a more consistent use of arable land (Sindik 1950). The traditional outline of Vrmac's rural settlements was already formed by the $19^{\text {th }}$ century. Nevertheless, this trend was to an extent cut short by the rise of industrialisation and infrastructural development provided by the Austrian authorities during the $19^{\text {th }}$ and the early $20^{\text {th }}$ centuries, which were mostly marked by the opening of military and industrial facilities, the construction of a new coastal vehicular route and the arrival of steamship lines to the Bay of Kotor.

The area of Stoliv as an established settlement was mentioned for the first time in 1326 as belonging to the district of Kotor (Lisavac et al. 2015). Apart from being partially owned by the Kotor nobility, the settlement was also under the influence of the town of Perast and the Abbey of St. George, located on the islet of the same name off the coast of Perast. However, the influence of the Perast nobility in the area of (Gornji) Stoliv continued only until the $15^{\text {th }}$ century (Butorac 1999). The architectural interventions of noblemen from the nearby towns in the area of Stoliv also led to the construction of several ecclesiastical buidlings, and the three churches in Gornji Stoliv and specifically that of St. Elijah, could be attributed to this trend. It should further be noted that a $16^{\text {th }}$ century inscription above the entrance portal to the church states that the building was "re-erected", suggesting an earlier, medieval origin of what may have previously been another building at the site. 

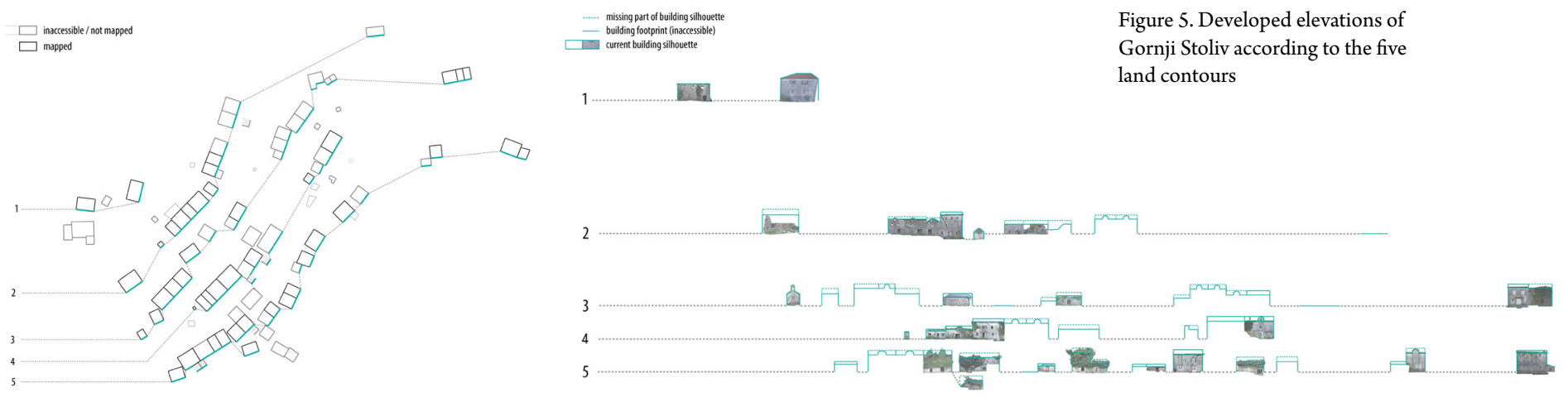

The inhabitants of Gornji Stoliv gradually turned to activities other than agriculture; this, coupled with the formation of the lower, coastal settlement of Donji Stoliv, allowed the inhabitants to begin to enjoy a degree of economic independence. This resulted in the designation of Gornji Stoliv as a municipality within the Republic of Venice in the late $18^{\text {th }}$ century (Lisavac et al. 2015). As the village reached its heyday in the 18th and the 19th centuries (Petrović 1956), the inhabitants were engaging in both agricultural and maritime activities. Gornji Stoliv's architectural fabric adopted its final form by merging its main thoroughfares with its churches and public spaces (squares) to the east of the village, with residential and other architectural units (stables, cisterns, wells) being organised along five main land-contour lines. This was done by extending brotherhood-based dwelling agglomerations in a linear manner (Fig. 5).

It was not before the early 1950s and when the area began to be abandoned (following the industrialisation of the region in the early $20^{\text {th }}$ century) that the architect Milan Zloković analysed the architectural fabric of the village (Fig. 6), alongside other Serbian architects.

Gornji Stoliv is now a shadow of its former self, both in its own right and with regards to the wider cultural landscape it is situated in.

Figure 6. Sketch of the village in 1950s (Milan Zloković)

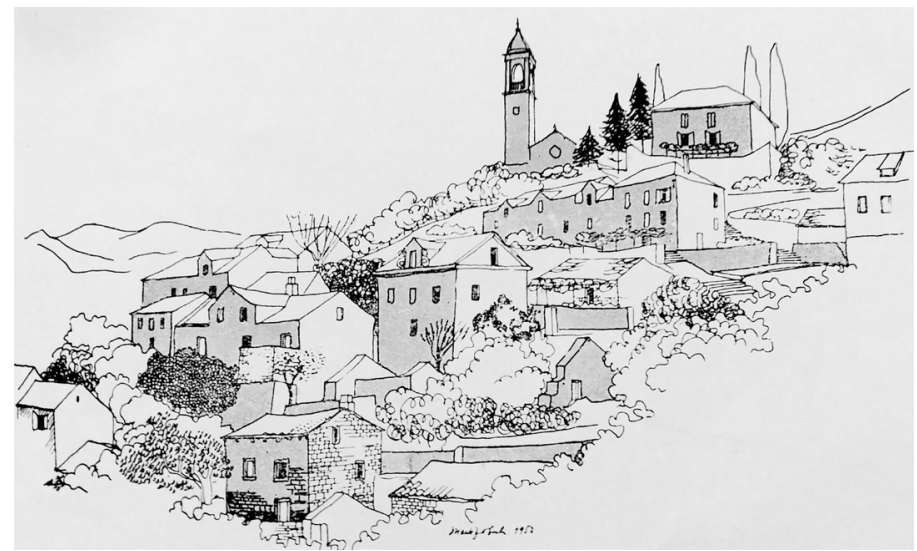

\section{Research overview}

The research on Gornji Stoliv was carried out as part of a Master's thesis ${ }^{1}$ between late 2018 and mid 2019. Its subject was a comprehensive set of analyses focusing on the history, architecture and heritage values of the settlement, as well as on its potential for revitalisation. The studies were made possible by the inspection of relevant written and archival materials, although these were limited in number; the other main source of analysis being site visits and observations. Institutionally, the research included work at the Historical Archives in Kotor, the Regional Directorate for the Protection of Cultural Properties in Kotor, the Town Library of Herceg Novi, the State Archives in Split, and the State Archives in Zadar. The research also led us to study archive material found in the State Archives in Venice, but no useful material was found there. Altogether, 53 buildings were analysed out of approximately 76 edifices surviving in the village to this day (Fig. 7). Their current configuration and inter-relatedness were analysed individually and in the context of their respective agglomerations. They were also considered in the context of the historical information available which was mainly derived from cadastral maps from 1838 (State Archives in Zadar) (Fig. 8) and 1872 (Historical Archives in Kotor) (Fig. 9), as well as a cadastral book from the 1870s (State Archives in Split), with the latter featuring information such as the function, ownership

Figure 7. Scope of analysis of the research

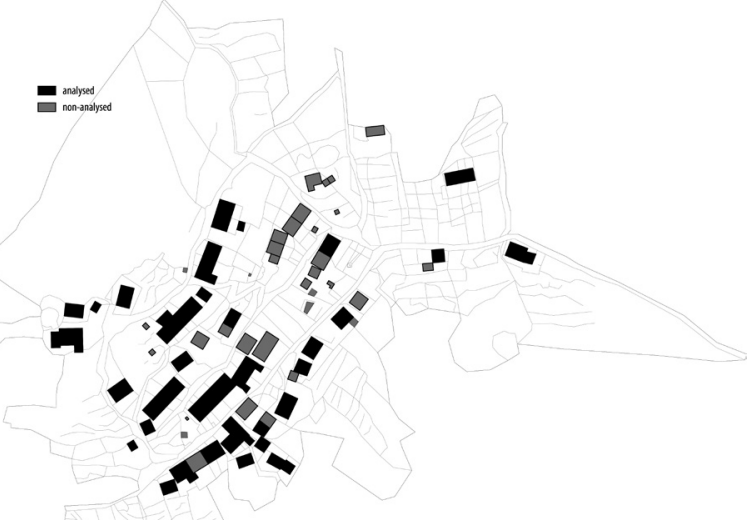




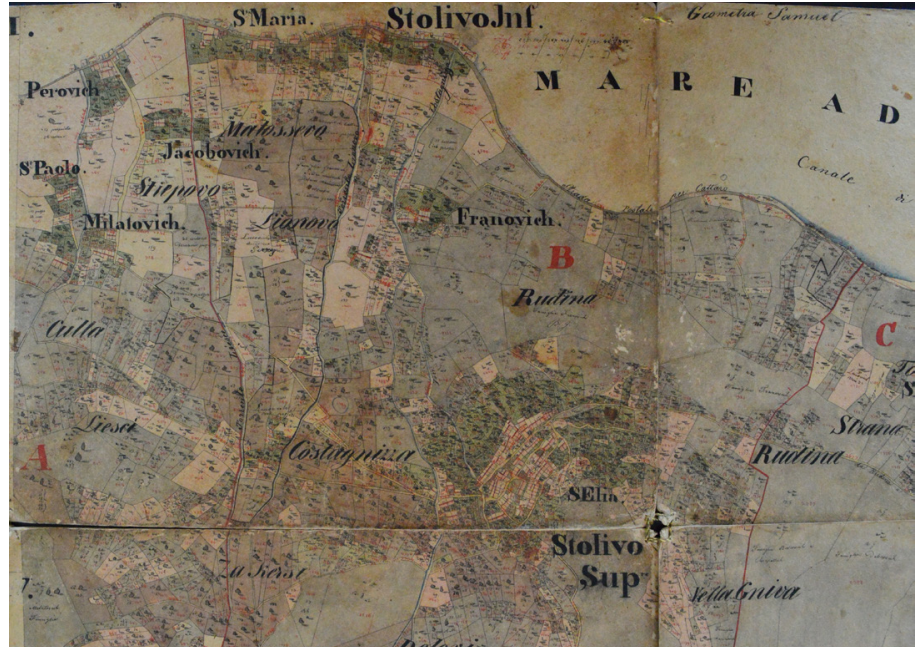

Figure 8. Cadastral map of the wider area of Stoliv from 1838 (HRDAZD-382 Uprava za katastarsku izmjeru, 1823-1839, Villagio Stolivo in Dalmazia Circolo di Cattaro, 1838: 183)

and size of the architectural units and plots in question. The urban and cultural-landscape analyses focused on how the settlement was related to the wider surroundings (Fig. 10) and the presence of public buildings and spaces (Fig. 11), whereas architectural analyses focused on revealing the embedded values of the largely dilapidated dwellings (Fig. 12) and economic buildings in the village. For practical purposes, the analysed buildings were all coded with respect to one of the five pertaining land-contour lines, while for each of the buildings within the analysis scope, a separate "building ID", or schematic matrix was developed. The architectural analyses could then be conducted upon this basis, as well as a proposal for revitalisation in the last phase of the research. The "building IDs" feature general information on the building, the types of degradation and the heritage values identified, as well as the existing

Figure 10. View from the village over the basins of Kotor and Risan

Figure 11. View of the churches of St. Anne and St. Elijah from one of the village squares

Figure 12. View of the islets of Perast through one of the windows of an abandoned house

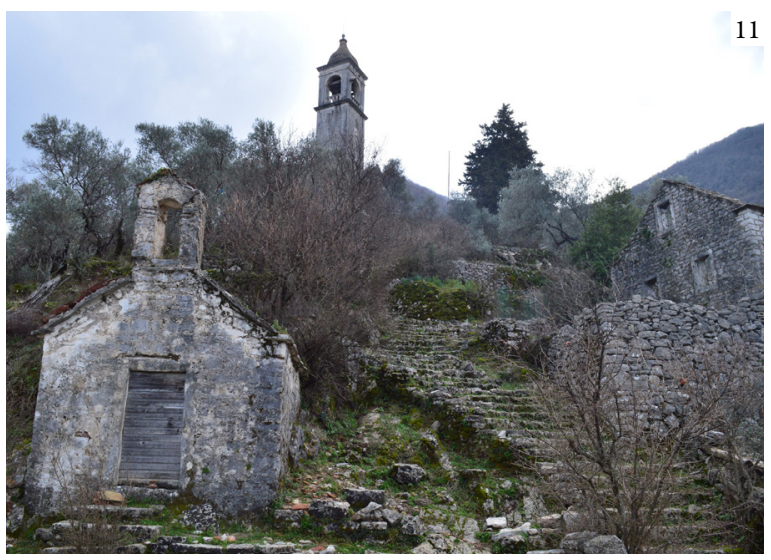

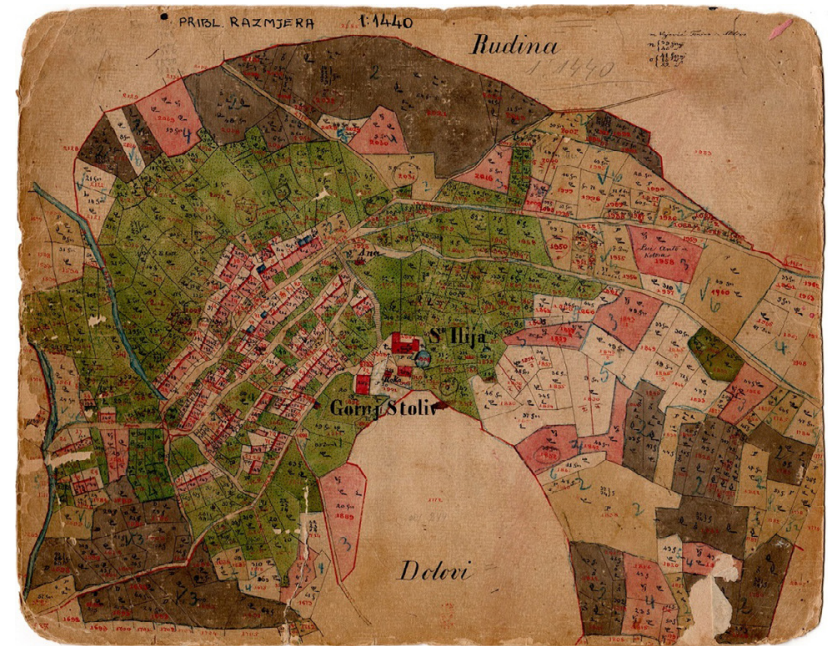

Figure 9. Cadastral map of the wider area of Stoliv from 1872 (DACG IAK Katastarska uprava Kotor, KO Stoliv, Identifikaciona skica Stoliv, 1872)

architectural elements, the necessary interventions and other relevant information pertaining to the building in question. The methodology of drafting "building IDs" and using the information gathered for different parts of the research draws on a similar methodological tradition employed by the national and local heritage conservation authorities in Montenegro when studying settlements in the Bay of Kotor such as Morinj, Risan, Perast, Prčanj and Donji Stoliv.
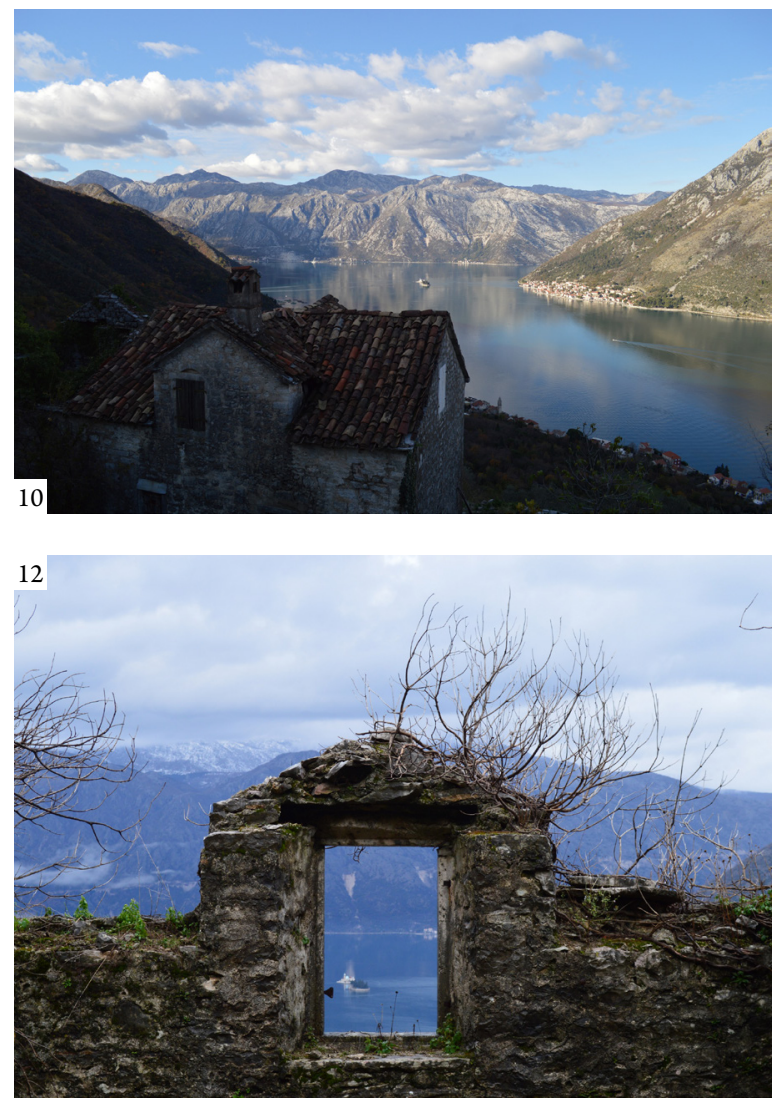
It should further be noted that, due to the fragmented nature of building ownership in the village, consultation with the inheritors of the analysed buildings (who often happen to be the descendants of Gornji Stoliv's former inhabitants) was limited. In addition, the relativelylow accessibility of the settlement prevented the use of advanced documentation equipment and meant that the capacity of independent researchers was limited to the use of conventional research techniques.

With regard to other stakeholders (including, but not limited to, the regional Directorate for the Protection of Cultural Properties in Kotor and the Diocese of Kotor, which owns a number of ecclesiastical and residential buildings in the village), it should be stressed that, with the growing pressures of mass tourism and uncontrolled urbanisation, as well as the lack of sufficient sources of funding for conserving the most affected parts of historic built environment in the Bay of Kotor, the overall revitalisation schemes for settlements such as Gornji Stoliv are still pending. On the other hand, the relevant Management Plan (Crepulja et al. 2011) for the World Heritage Site in question states the issues of the lack of a strategic vision of touristic development for it, the clash of the development concepts with the potentials of the site, the absence of a study on the cultural landscape and the Bay of Kotor, etc. It also proposes the stimulation of respect for the legal framework of urbanisation, the drafting of studies on the protection of cultural properties in all pertaining settlements, as well as a touristic strategy for the site, the practical integration of potential conservation activities within Gornji Stoliv and all of the World Heritage Site. Unfortunately, this plan is still at the level of discussion only, and a matter of research for a limited number of NGOs and individual heritage conservation firms and professionals.

Figure 13. State of conservation of buildings and plots in the village Figure 14. Example of a public stairway in the village

Figure 15. View of a public stairway and the church of St. Elijah

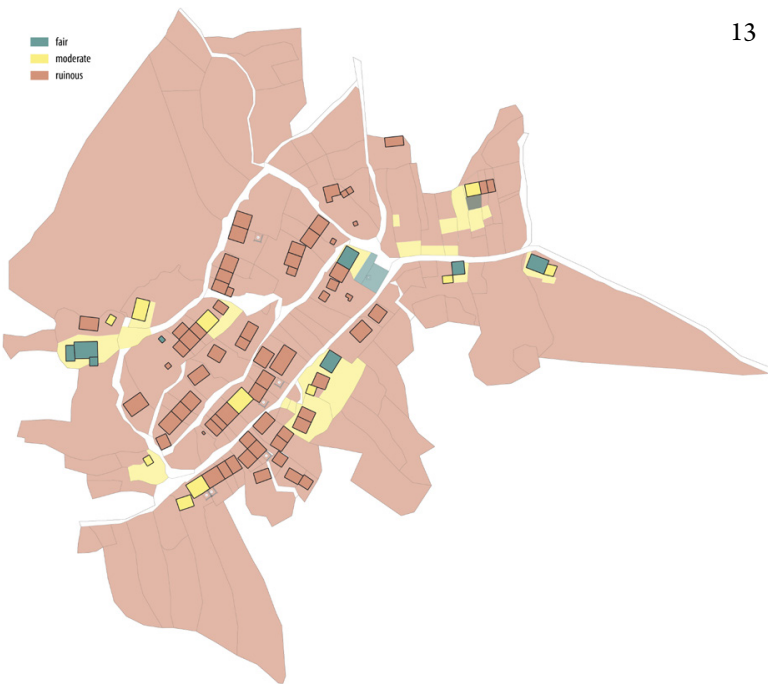

\section{Research outcomes}

\section{$\underline{\text { Urban analyses }}$}

As part of the research, urban analyses were subdivided into the following sections: pathway infrastructure, external qualities (visual connection of the settlement within itself and with the surroundings), public spaces, building and plot functions, and overall state of conservation (Fig. 13).

Regarding infrastructure, the historical thoroughfares of the village are mostly paved in stone and are spontaneously formed as a way of connecting the main pathways, which can be divided as follows: general pathways, steep thoroughfares (ramps), combinations of ramps and stairways, and stairways proper. The overall infrastructure
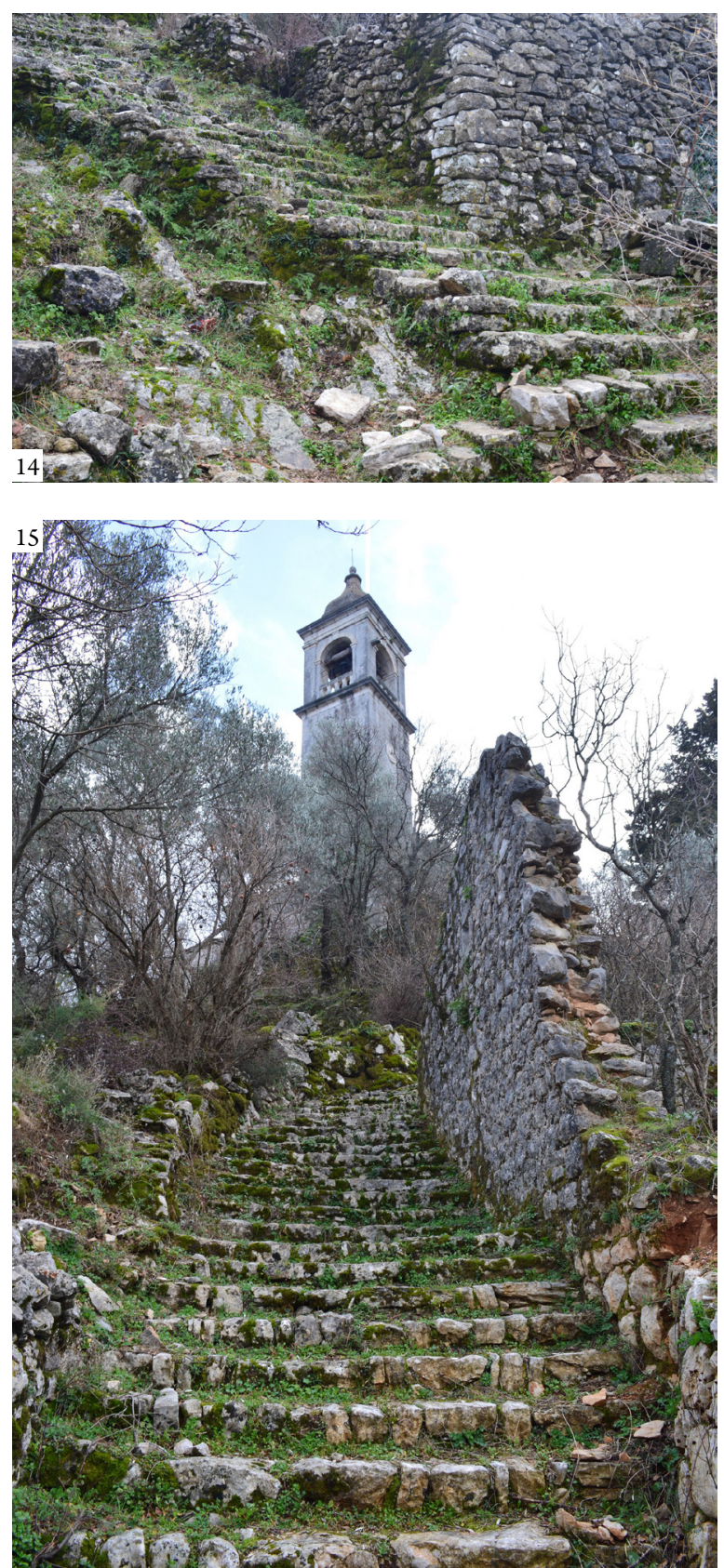
is marked by two pathways following two respective land contours, intersected by public stairways (Fig. 14), and built using the drywall technique, as are the rest of the infrastructure, retaining walls and stone fences in the village. The spontaneity of the infrastructure, however, can be disputed, given the characteristic vista points opening up from some of the main thoroughfares (Fig. 15). The pathway infrastructure in the village had to be analysed to ascertain how communication between individual architectural units in the settlement was organized. It suggested a complex network of different infrastructural categories developed with respect to, but not limited to, the proximity of the vast agricultural plots, the proximity to the public spaces and the "ecclesiastical axis", the need to navigate through the terraced configuration of the settlement, etc.

Public spaces and buildings in the village are, at first observation, organised with the same degree of spontaneity as the infrastructure. Nevertheless, the position of two squares and three churches at the eastern border of the village (the aforementioned "ecclesiastical axis") may indicate that this was the starting point, or the earliestformed portion of Gornji Stoliv's built environment, from where the residential fabric subsequently developed. On the other hand, the one public cistern is located close to the entrance to the village, while other cisterns of more modest dimensions (arguably originally privately-owned) are attached to the associated dwellings, but scattered, in line with the density of the surrounding architectural units. In addition, the position of semi-public terraced spaces in front of the majority of residential units suggests a peculiar urban quality formed within the terraced character of Gornji Stoliv. Each of the building rows, developed along land contours, does not block the view for the row of houses located at the higher altitude. It also seems that they satisfied both the leisure and economic needs of their occupants, as there are stables close to many house agglomerations, and what appear to have been vegetable gardens at the rear of the houses. Regarding the historical functions of plots in Gornji Stoliv, the archive documents show that the majority of arable land surrounding the settlement was used as olive groves, which is further attested by the surviving plants.

As for the state of conservation of the buildings and plots in the village, the units were designated as either fairly-, moderately-, or ill-preserved (in ruins). It should be noted that the ecclesiastical heritage in the village, alongside several upkept houses (suggesting their occasional/ seasonal habitation) have fared considerably better than the majority of the ruined dwellings, and those public units suffering from neglect and the effects of rains and humidity. Most of the agricultural plots were found to be covered by maquis and/or other plant species and therefore unsuitable for their traditional purposes. The types of deterioration are described for each architectural unit analysed as part of the "building ID" documentation, which lays the foundation for a comprehensive set of conservation measures to be

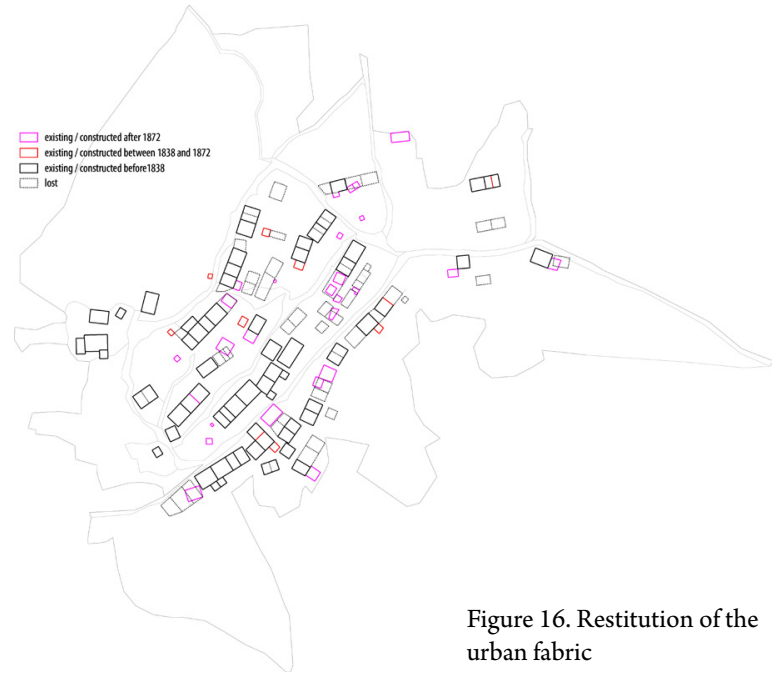

carried out throughout the whole settlement and according to the type of deterioration, within a future revitalisation process.

\section{$\underline{\text { Urban-historical analyses }}$}

The study of cadastral maps from the State Archives in Zadar and the Historical Archives in Kotor, as well as from the cadastral book inspected in the State Archives in Split, has revealed that Gornji Stoliv, as noted previously, developed along five main land contours. The form of the settlement is marked by the presence of public and ecclesiastical units at one end of the village, whereas the everyday and economic activities were found to have been concentrated towards the arable plots to the north-west. The same archive material was used to plan a historical restitution of the village, which shows the position of lost buildings, as well as indicating the periods in which the buildings were constructed (pre-1838, 1838-1872, and post-1872) (Fig. 16). The research shows that the main features of the village, including the organisation of residential units into clusters, or brotherhood-based agglomerations, was already formed by 1838 and that the post- 1838 period saw only a partial loss and erection of new buildings within the settlement.

\section{$\underline{\text { Architectural-historical analyses }}$}

Upon evaluating "building IDs" for each of the buildings analysed in Gornji Stoliv, the need arose to create a matrix of building typologies, based on shared architectural characteristics, with each of the analysed buildings assigned to its respective typology. Materials, construction techniques and architectural elements, across all of the village, have also been documented, including: walls, openings (doors and windows), roof coverings, roof belvedere units, various exterior elements (such as eaves and chimneys), various interior elements (such as niches and a fireplace), horizontal structures (Fig. 17), partition walls and interior surface renderings. The documented materials, construction techniques and architectural elements have been analysed according to the relevant 

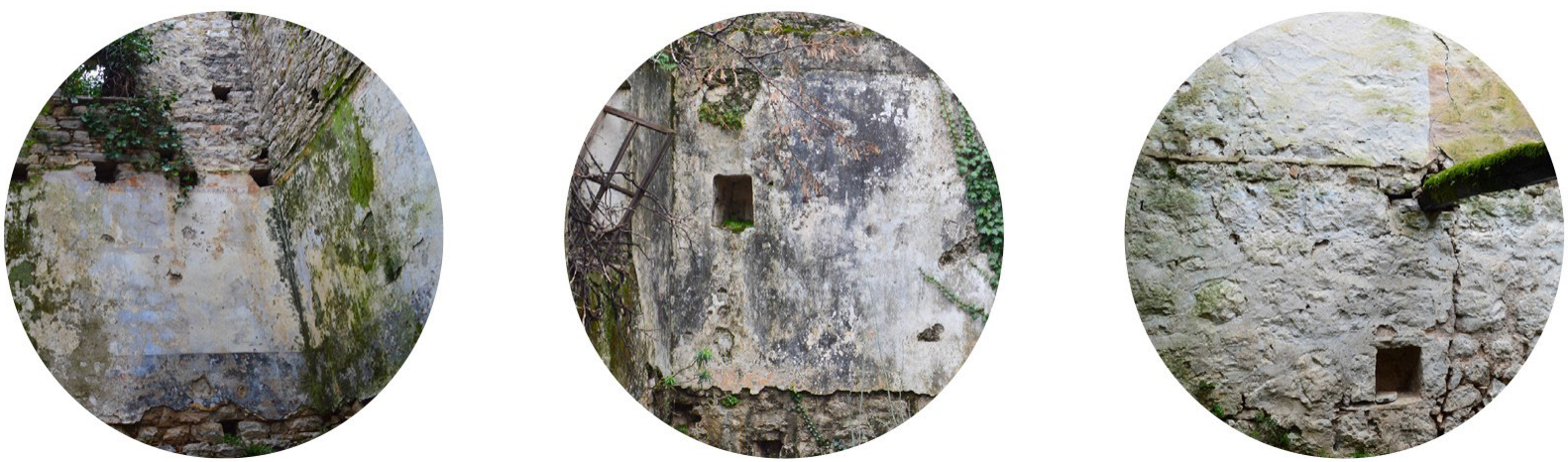

Figure 17. Remains of different types of floor structure

building typology detected, producing a set of respective matrices that can be used in future stylistic-chronological analyses of the buildings, once further research on site takes place. For instance, three types of horizontal structure typologies have been detected throughout the village: 1) a floor deck supported by wooden beams inserted directly into walls; 2) a floor deck supported by wooden beams which are in turn supported by stone cantilevers; and 3) a floor deck supported by wooden beams resting on indented

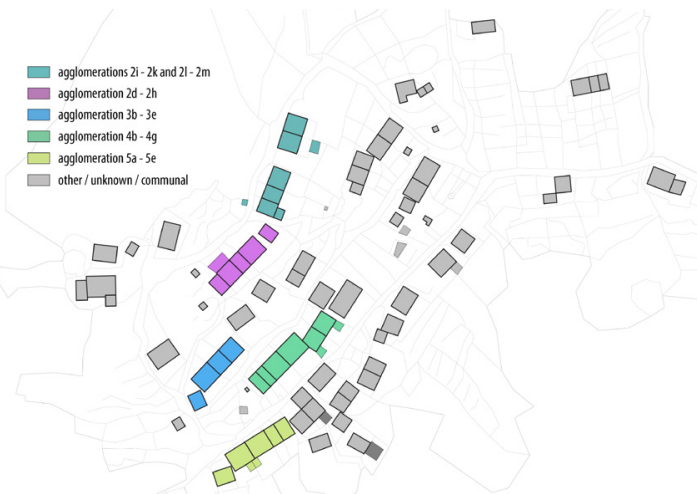

Figure 18. Analysis of groups of buildings wall tops of the storey below. By using the relevant "building ID" documentation, it was possible to produce matrices showing exactly which material, construction technique or architectural element was detected in which building typologies, creating a broad data set which could further be used for identifying similarities and differences among the building typologies ascertained previously and allowing for a more complete architectural language of the settlement. Alongside the architectural-historical analyses, it was also necessary to research several building agglomerations with respect to the information found in the archives (Fig. 18). Agglomeration 5a-5e, which was deemed to be of particular historical and architectural interest, was, unlike other agglomerations, analysed with respect to its outline in 1838, 1872 and what was found on site in 2019 (Fig. 19). As a result of this particular analysis, it was ascertained that this residential cluster of buildings formerly featured a set of three adjoining buildings, as attested to in the 1838 cadastral map. Nevertheless, the 1872 cadastre, not featuring the adjoining buildings, shows they must have been lost prior to the construction of a stable which was detected at their location in 2019. Furthermore, through the analysis of the cadastral book of 1870s (State Archives in Split) and

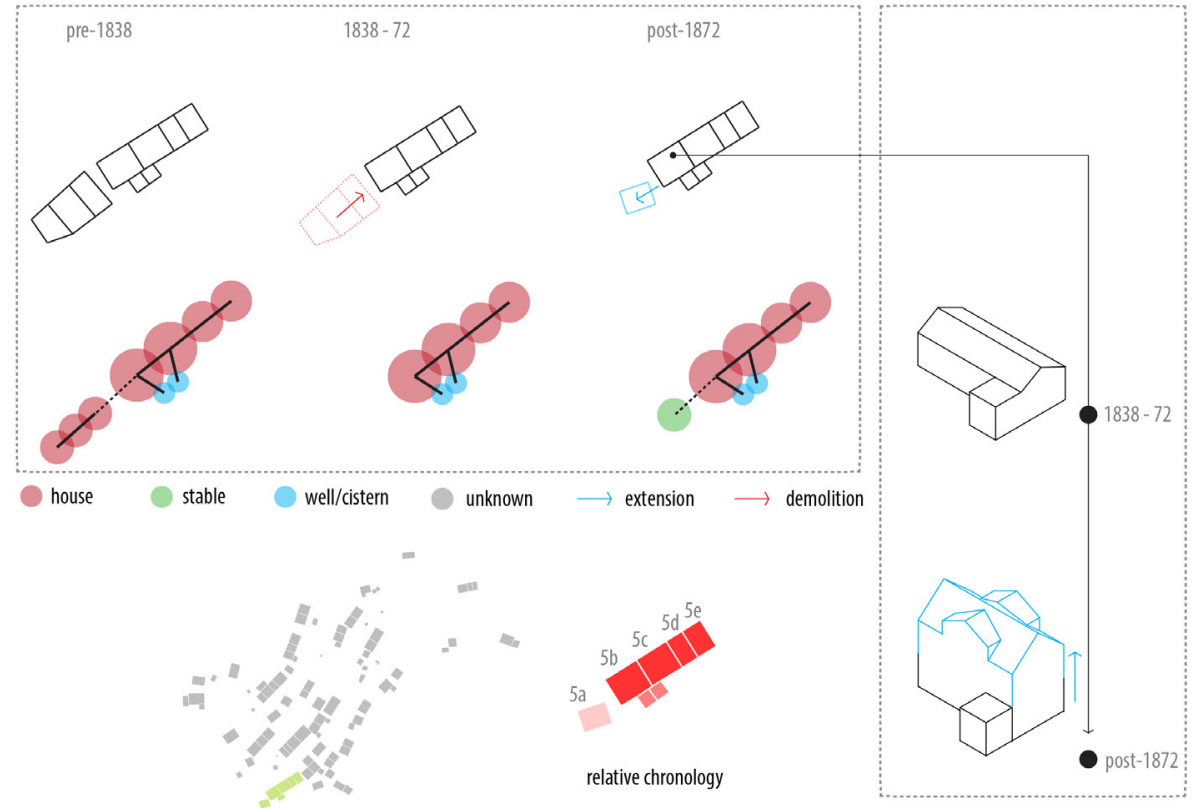

Figure 19. Example of group of buildings (State Archives in Zadar, Historical Archives in Kotor) 


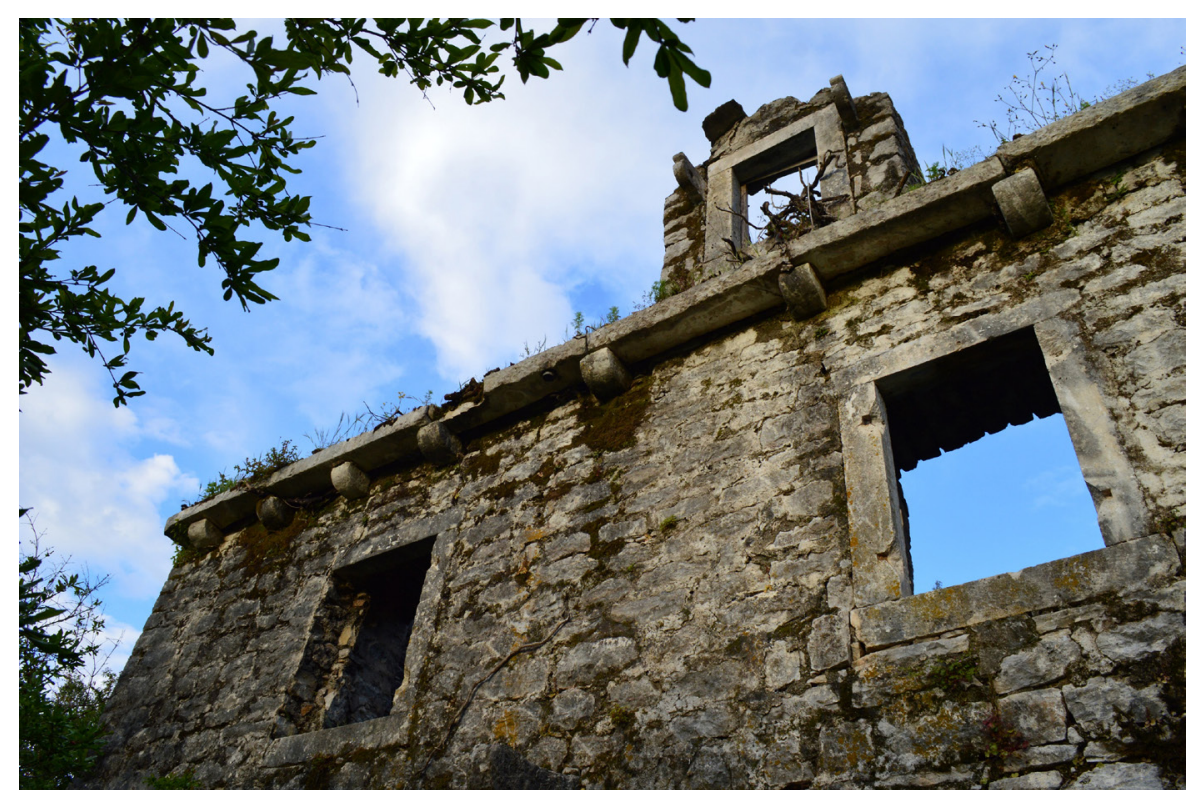

Figure 20. Case study which was selected for a revitalisation proposal the footprint of the building, it has also been ascertained that building $5 \mathrm{~b}$ was extended vertically in the post- 1872 period, when it was transformed into one of Gornji Stoliv's more complex dwellings, featuring a belvedere. This shows that the main dwellings of the village, unlike the majority of Gornji Stoliv's vernacular buildings, may not always have been completely new constructions, but also upgrades of previously-existing dwellings.

As a conclusion to the comprehensive analyses conducted in the settlement, a proposal for revitalisation has been put forward at both urban and architectural levels. The house coded as 21 has been chosen as a research centre to accommodate scholars-in-residence in a possible future revitalisation of Gornji Stoliv (Fig. 20). It emerges that re-establishing the former sense of community of individual house agglomerations is important to a proposal for comprehensive revitalisation. By conceiving them as individual clusters for academic or other purposes, one building in each agglomeration is to be considered as "central" or as a logistic centre for the rest of the agglomeration, whatever its future potential function. Additionally, it has been decided that the mills, churches and the squares will retain their original public functions in the service of a revitalised, dynamic social environment (Fig. 21 ). On the other hand, revitalisation of the surrounding plots also requires restoring olive groves, terraces, gardens and general public spaces (Fig. 22). House 21 is taken as an example of a specific restoration proposal, despite the information missing on many of its original features. The matrix of building typologies is used in this way, with house 21 ascertained to belong to the same category as houses $2 \mathrm{~m}$ and $3 \mathrm{~m}$ (residential - $7 \mathrm{~b}$ building typology). Following the principle of analogical restitution and in the absence of necessary documentation on the former state of the building, it has been proposed to restore house 21 using the architectural elements found in similar building units $(2 \mathrm{~m}$ and $3 \mathrm{~m}$ ), with the result being a coherent, and arguably
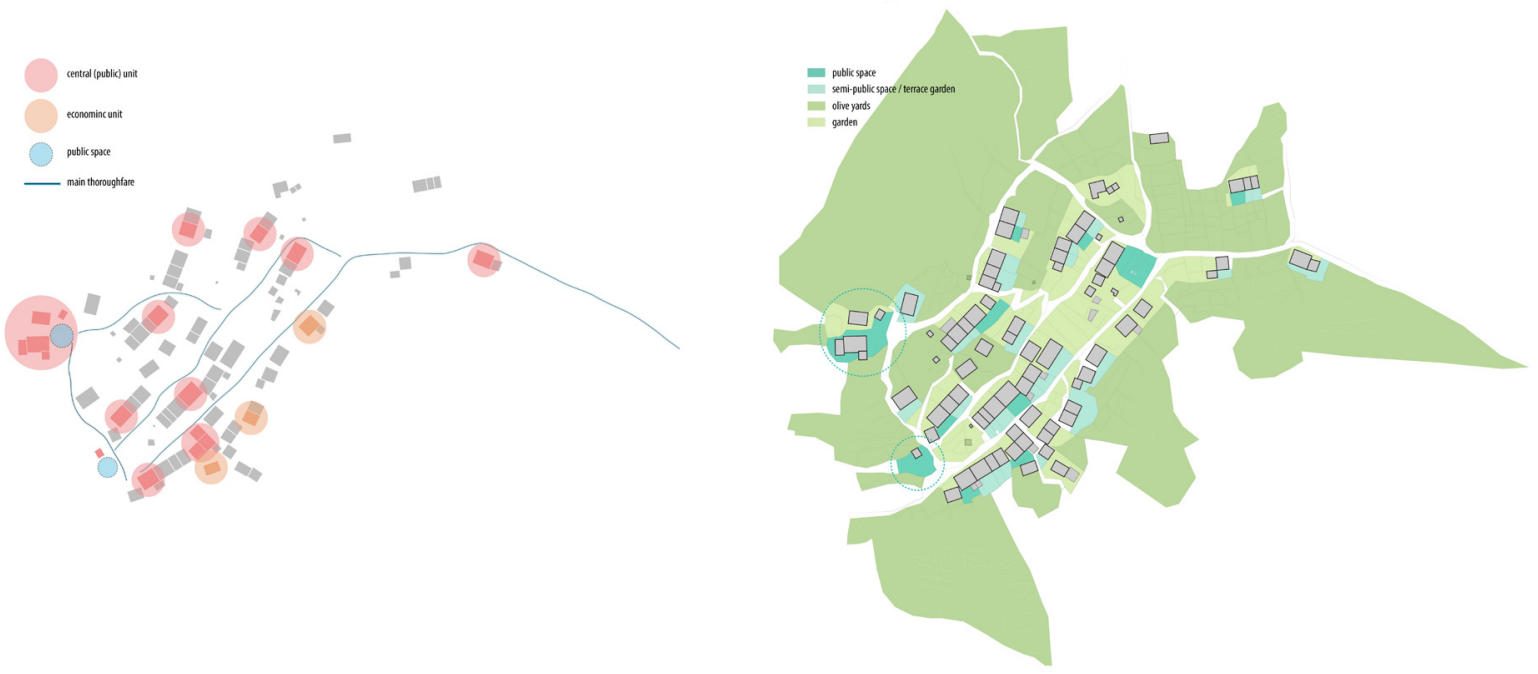
scientifically-sound restoration proposal (Figs. 23, 24, 25, 26 and 27), respecting the original architectural elements, specifically those of the horizontal structure typology, with their interiors being re-adapted so as to accommodate the central function within the revitalised agglomeration that the building belongs to.

\section{Conclusions}

In the study of a vernacular historic environment, such as that of Gornji Stoliv, the presence of written and archive documents, however limited, is of crucial importance for conducting comparative historical and urban architectural analyses. Nevertheless, in the absence of (sufficient) material of this nature, it has been discovered that the material evidence embedded in the urban and architectural fabric can be equally informative when it comes to drawing conclusions as to the history and values of an ensemble subject to analysis, as well as for possible restoration proposals. The case of Gornji Stoliv proves that limitations to one source of information can be compensated by information from another one. Additionally, the limitations encountered in conducting research such as the one on Gornji Stoliv can be overcome by considering similar

Figure 23. Elevation of house 21 after its proposed restoration Figure 24. Section of house 21 after its proposed restoration Figure 25. Ground-floor plan of house 21 after its proposed restoration Figure 26. First-floor plan of house 21 after its proposed restoration Figure 27. Second-floor plan of house 21 after its proposed restoration

23

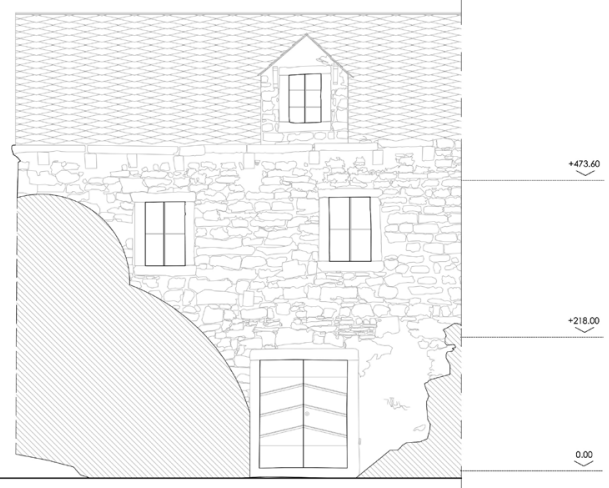

24

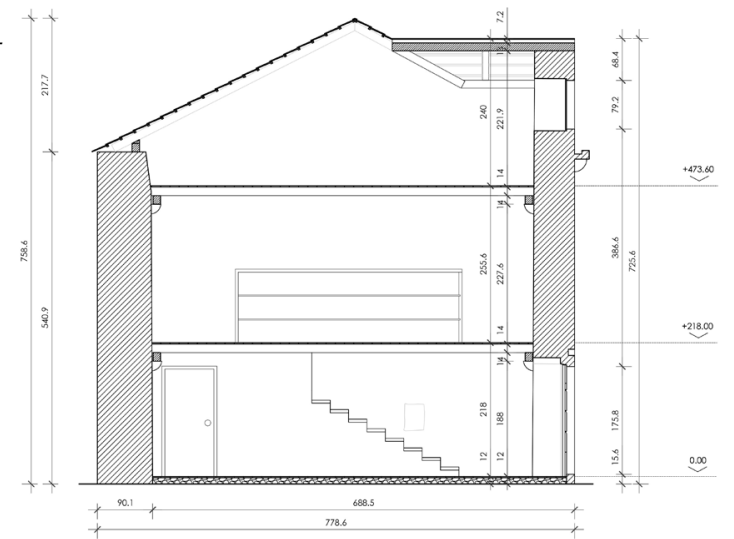

historic ensembles within the Adriatic region and a wider geographical area when envisioning future revitalisation schemes. It should therefore be noted that further research on Gornji Stoliv on a wider scale remains necessary in order to envisage a complete and scientifically-sound set of restoration guidelines.

Given the complex nature of the settlement, the following stakeholders should be involved in a potential comprehensive revitalisation scheme: the descendants of Gornji Stoliv's former inhabitants and building owners (including both foreigners and Montenegrin nationals), the local community of Donji Stoliv, the regional Directorate for the Protection of Cultural Properties in Kotor, the Diocese of Kotor, the local NGO sector, local heritage professionals and any other relevant institutions and individuals whose professional activities relate to the research on and active protection of the cultural heritage in the Bay of Kotor.

27

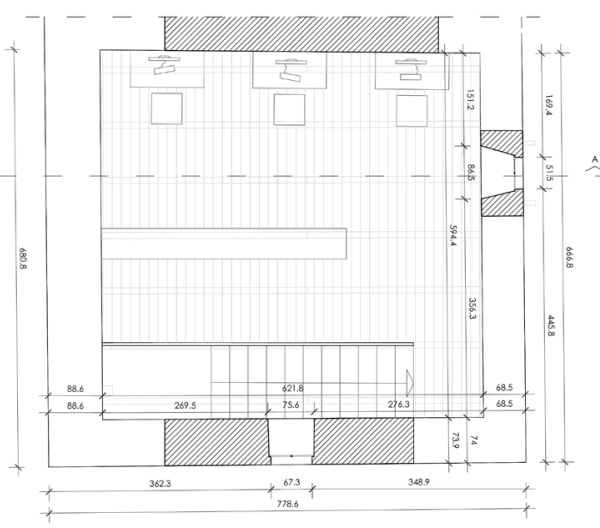

26

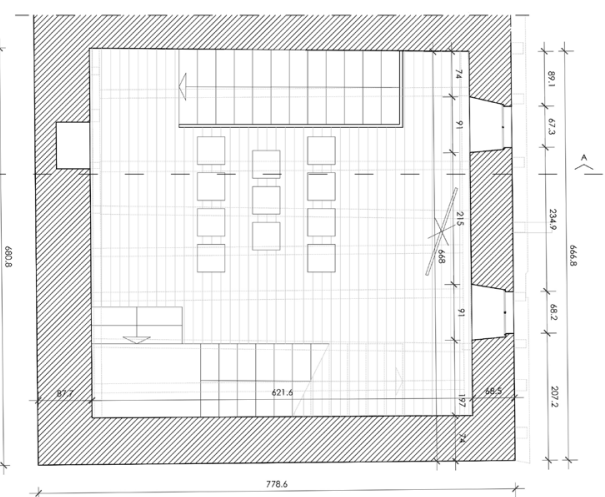

25

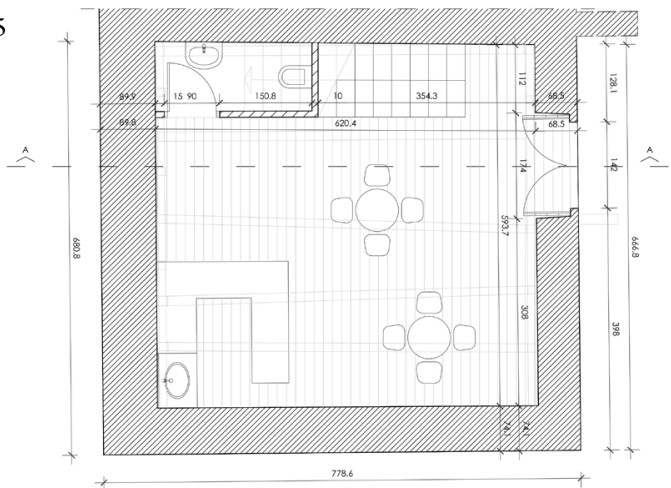


In the wake of uncontrolled urbanisation in its immediate surroundings, the village of Gornji Stoliv is deemed to be a prime example of a historic residential ensemble on which to apply current approaches to architectural conservation, and for which a sustainable development plan is required. An approach that follows the principles of sustainable development must therefore consider the economic potential of Gornji Stoliv's natural surroundings, including the possible recovery of its historic crops, while the urban fabric must be revitalised in a way which can provide an alternative to the negative urbanisation patterns and trends that have been taking place in the Bay of Kotor in the past decades.

The overall approach has to build on the identified spatial qualities of the settlement, while addressing the immediate and long-term needs of the stakeholders within the scope of applicable heritage conservation principles. In practical terms, the restoration proposals need analogical research into different buildings and building typologies, whereas a platform based on a Geographic Information System (GIS) software would facilitate easier handling of the acquired data sets, including those on materials, construction techniques, architectural elements, building typologies, building agglomerations, building and land uses (both former and current, if applicable), information on the state of conservation, etc.

The need for further research with the use of a GIS-based platform and advanced technical equipment opens up the possibility of educational activities being integrated into the initial revitalisation phases in Gornji Stoliv. While the research presented in this paper proposes revitalising the settlement based on the organisation of functional clusters within the formerly-established house agglomerations, other alternative solutions, which would allow for the creation of a self-sufficient economic and social environment whilst respecting the material and visual integrity of Gornji Stoliv's urban fabric and natural surroundings, are also viable alternatives.

Finally, despite the current trends of urbanisation and, more importantly, that of commercial exploitation of heritage for tourism, the institutions and professionals in charge of the future restoration schemes for Gornji Stoliv will need to take heed of the identified heritage values embedded in each of the village's units and plots, with all aspects of the buildings being taken into account. In this respect, the Gornji Stoliv settlement could play a pivotal role in the approach to restoring similar abandoned or decaying historic villages and towns within the Adriatic region.

\footnotetext{
${ }^{1}$ The Master's thesis to obtain the degree of Master of Science in Conservation of Monuments and Sites, conducted under the supervision of professors Barbara Van der Wee (KU Leuven), Krista De Jonge (KU Leuven), Rifat Alihodžić (Univerzitet Crne Gore) and Daniele Pini (Università degli Studi di Ferrara). For more information, see: Kovačević, Adis. 2019. Solutions for a comprehensive model for conserving vernacular heritage in the Bay of Kotor through the example of the village of Gornji Stoliv (Master's thesis, Raymond Lemaire International Centre for Conservation - KU Leuven, 2019). Leuven: KU Leuven.
}

\section{Bibliography $\mid$ Bibliografía | Bibliografia}

Butorac, Pavao. 1999. Kulturna povijest grada Perasta. Cultural History of the Town of Perast. Perast: Gospa od Škrpjela.

Crepulja, Tvrtko; Čađenović, Novak: Čavlović, Nemanja; Čubrović, Zorica; Čulić, Gracijela; Gligorić, Biljana; Grgurević, Jasminka; Ilić, Zorica; Jablan, Danijela; Joksimović, Aleksandar; Jokileto, Juka; Kapetanović, Aleksandra; Konjević, Vanja; Krestev, Todor; Lalošević, Ilija; Lisicin, Katri; Martinović, Jovica; Milošević, Miloš; Pasinović, Milenko; Petričević, Milo; Radonjić, Bose; Simović, Snježana; Stanovčić, Tatjana; Vičević, Vesna; Vučenović, Svetislav; and Vujičić, Rajko. 2011. Menadžment Plan Prirodnog i kulturno-istorijskog područja Kotora. Cetinje: Ministarstvo kulture.

Kojić, Branislav. 1953a. Seoska arhitektura u Kotorskom zalivu. Belgrade: Spomenik.

Kojić, Branislav. 1953b. Gornja sela na poluostrvu Vrmcu u Boki Kotorsko. Belgrade: Spomenik.

Lisavac, Katarina; Mihaliček, Marija; Popović, Ana; and Vrzić, Milena 2015. Kulturna baština Vrmca. Tivat: Opština Tivat, Kulturnozavičajno udruženje Napredak Gornja Lastva. Kotor: Expeditio Centar za odrivi razvoj.

Lisavac, Katarina. 2019. Mapiranje kulturnog nasleđa Vrmca. Moderna Konzervacija, 6: 145-163. Belgrade: ICOMOS Serbia National Committee.

Mažibradić, Anita. 2016. Tivat kroz stoljeća: mjesto kmetova i gospodara. Zagreb: Hrvatsko nacionalno vijeće Crne Gore.

Petrović, Zoran. 1956. Selo i seoska kuća u Boki Kotorskoj. Belgrade: Zbornik Arhitektonskog fakulteta u Beogradu.

Sindik, Ilija. 1950. Komunalno uredenje Kotora od druge polovine XII do početka XV stoleća. Belgrade: Naučna knjiga.

\section{Biography $\mid$ Biografía $\mid$ Biografia}

\section{Adis Kovačević}

He was born in Kotor, Montenegro, in 1994, and grew up in the neighbouring town of Herceg Novi. Having lived in Montenegro, Bosnia and Herzegovina, Turkey and Belgium, he completed his highschool, undergraduate and postgraduate studies in an international and interdisciplinary context. He has been trained as an architect (Orta Doğu Teknik Üniversitesi, Ankara) and a cultural heritage specialist (Raymond Lemaire International Centre for Conservation, KU Leuven). Adis is currently employed as a conservation architect and is engaged in heritage conservation projects in the Bay of Kotor. 